\title{
Allozyme and chloroplast DNA variation in Italian and Greek populations of Pinus leucodermis
}

\author{
G. BOSCHERINI, M. MORGANTE†, P. ROSSI \& G. G. VENDRAMIN* \\ Istituto Miglioramento Genetico Piante Forestali, C.N.R., via Atto Vannucci 13, 50134 Firenze and tDipartimento di \\ Produzione Vegetale e Tecnologie Agrarie, Università degli Studi, via Fagagna 209, 33100 Udine, Italy
}

\begin{abstract}
Allozyme and chloroplast (cpDNA) variation was examined in five Italian and two Greek populations of Pinus leucodermis Ant. to estimate levels of genetic variability within and among populations and to establish the usefulness of allozyme and cpDNA markers in the taxonomic classification of these populations. Twenty-three isozyme gene loci were analysed, as well as restriction fragment length polymorphisms at two cpDNA spacer regions between tRNA genes. The level of genetic variability tended to be lower in the Greek populations but overall the observed levels of allozyme variation within and among populations were similar to those of other conifers. Identical cpDNA amplification and restriction patterns were observed among all individuals sampled from the seven populations. Taken together, the results of the allozyme and cpDNA analyses indicate that all seven populations belong to the same biological species.
\end{abstract}

Keywords: allozymes, chloroplast DNA, genetic variability, Pinus leucodermis.

\section{Introduction}

Pinus leucodermis Ant. is a wind-pollinated conifer species and one of the most narrowly distributed pines in Europe. Its natural range is divided into two main parts, each constituted of small and distinct populations, located either in southern Italy or the Balkan peninsula. Palynological studies show that this species was once a major component of forests in southern Italy (Avolio, 1984). The systematic and phylogenetic relationships between the two groups of populations have tended to remain unclear; according to some authors they represent two different species, $P$. leucodermis and $P$. heldreichii, while other authors (e.g. Mirov, 1967) consider all populations to belong to the same species. Both views are mainly based on morphological and crossability analyses. Recently, isozyme and chloroplast DNA (cpDNA) analyses have been used to reconstruct the phylogenetic relationships among conifer forest tree species (Sigurgeirsson \& Szmidt, 1988; Szmidt et al., 1988; Wang \& Szmidt, 1990; Shurkhal et al., 1992; Wagner et al., 1992). Most cpDNA analyses conducted to date have examined restriction fragment length polymorphisms (RFLPs) over the entire chloroplast genome or nucleotide sequences of a single gene.

*Correspondence.
Recently the polymerase chain reaction (PCR) has been used to amplify specific cpDNA sequences which have then been subjected to RFLP analysis using four-base restriction endonucleases (Liston, 1992; Rieseberg et al., 1992).

In the present study allozyme and chloroplast DNA (cpDNA) markers have been used to estimate levels of genetic variability within and among Italian and Greek populations of Pinus leucodermis, as well as to establish their usefulness for taxonomic classification. Using cpDNA we amplified and analysed by restriction enzyme digestions two spacer regions located between two pairs of tRNA genes (Taberlet et al., 1991).

\section{Materials and methods}

Seeds were collected from seven wild populations of Pinus leucodermis (Tables 1 and 2), five of which are located in the south of Italy (in the La Spina and Pollino mountain groups) while two occurred in Greece (in the Olimpo and Pindo mountains). The first Greek population clearly belonged to the group classified as $P$. leucodermis, while the second population was comprised of a type classified by some authors as $P$. leucodermis and by others as $P$. heldreichii. Seeds were collected from between 17 and 29 single trees in the five Italian populations; the exact number of trees sampled for seed in the two Greek populations is unknown but was greater than 30 . 
Table 1 Allele frequencies in Italian and Greek populations of Pinus leucodermis

\begin{tabular}{|c|c|c|c|c|c|c|c|c|}
\hline \multirow[b]{2}{*}{ Locus } & & \multicolumn{7}{|c|}{ Population } \\
\hline & & 1 & 2 & 3 & 4 & 5 & 6 & 7 \\
\hline Aco- $a$ & $\begin{array}{l}1 \\
2\end{array}$ & $\begin{array}{l}0.879 \\
0.121\end{array}$ & $\begin{array}{l}0.821 \\
0.179\end{array}$ & $\begin{array}{l}1.000 \\
0.000\end{array}$ & $\begin{array}{l}0.806 \\
0.194\end{array}$ & $\begin{array}{l}0.975 \\
0.025\end{array}$ & $\begin{array}{l}0.898 \\
0.102\end{array}$ & $\begin{array}{l}0.923 \\
0.077\end{array}$ \\
\hline$G 6 p d-a$ & $\begin{array}{l}1 \\
2\end{array}$ & $\begin{array}{l}0.241 \\
0.759\end{array}$ & $\begin{array}{l}0.483 \\
0.517\end{array}$ & $\begin{array}{l}0.324 \\
0.676\end{array}$ & $\begin{array}{l}0.263 \\
9.737\end{array}$ & $\begin{array}{l}0.250 \\
0.750\end{array}$ & $\begin{array}{l}0.434 \\
0.566\end{array}$ & $\begin{array}{l}0.727 \\
0.273\end{array}$ \\
\hline Got-a & $\begin{array}{l}1 \\
2\end{array}$ & $\begin{array}{l}0.000 \\
1.000\end{array}$ & $\begin{array}{l}0.017 \\
0.983\end{array}$ & $\begin{array}{l}0.088 \\
0.912\end{array}$ & $\begin{array}{l}0.225 \\
0.775\end{array}$ & $\begin{array}{l}0.175 \\
0.825\end{array}$ & $\begin{array}{l}0.000 \\
1.000\end{array}$ & $\begin{array}{l}0.000 \\
1.000\end{array}$ \\
\hline Got-b & $\begin{array}{l}1 \\
2\end{array}$ & $\begin{array}{l}0.017 \\
0.983\end{array}$ & $\begin{array}{l}0.052 \\
0.948\end{array}$ & $\begin{array}{l}0.029 \\
0.971\end{array}$ & $\begin{array}{l}0.025 \\
0.975\end{array}$ & $\begin{array}{l}0.000 \\
1.000\end{array}$ & $\begin{array}{l}0.000 \\
1.000\end{array}$ & $\begin{array}{l}0.000 \\
1.000\end{array}$ \\
\hline Got-c & $\begin{array}{l}1 \\
2 \\
3 \\
4\end{array}$ & $\begin{array}{l}0.000 \\
0.879 \\
0.052 \\
0.069\end{array}$ & $\begin{array}{l}0.000 \\
1.000 \\
0.000 \\
0.000\end{array}$ & $\begin{array}{l}0.029 \\
0.971 \\
0.000 \\
0.000\end{array}$ & $\begin{array}{l}0.050 \\
0.925 \\
0.025 \\
0.000\end{array}$ & $\begin{array}{l}0.050 \\
0.950 \\
0.000 \\
0.000\end{array}$ & $\begin{array}{l}0.000 \\
1.000 \\
0.000 \\
0.000\end{array}$ & $\begin{array}{l}0.000 \\
1.000 \\
0.000 \\
0.000\end{array}$ \\
\hline$I d h-b$ & $\begin{array}{l}1 \\
2\end{array}$ & $\begin{array}{l}0.052 \\
0.983\end{array}$ & $\begin{array}{l}0.000 \\
1.000\end{array}$ & $\begin{array}{l}0.029 \\
0.971\end{array}$ & $\begin{array}{l}0.053 \\
0.947\end{array}$ & $\begin{array}{l}0.000 \\
1.000\end{array}$ & $\begin{array}{l}0.000 \\
1.000\end{array}$ & $\begin{array}{l}0.000 \\
1.000\end{array}$ \\
\hline$L a p-a$ & $\begin{array}{l}1 \\
2\end{array}$ & $\begin{array}{l}0.948 \\
0.052\end{array}$ & $\begin{array}{l}0.931 \\
0.069\end{array}$ & $\begin{array}{l}0.971 \\
0.029\end{array}$ & $\begin{array}{l}0.925 \\
0.075\end{array}$ & $\begin{array}{l}1.000 \\
0.000\end{array}$ & $\begin{array}{l}0.888 \\
0.112\end{array}$ & $\begin{array}{l}0.981 \\
0.019\end{array}$ \\
\hline$L a p-b$ & $\begin{array}{l}1 \\
2\end{array}$ & $\begin{array}{l}0.839 \\
0.161\end{array}$ & $\begin{array}{l}0.879 \\
0.121\end{array}$ & $\begin{array}{l}0.906 \\
0.094\end{array}$ & $\begin{array}{l}0.925 \\
0.139\end{array}$ & $\begin{array}{l}1.000 \\
0.000\end{array}$ & $\begin{array}{l}0.423 \\
0.577\end{array}$ & $\begin{array}{l}0.567 \\
0.433\end{array}$ \\
\hline$M d h-b$ & $\begin{array}{l}1 \\
2\end{array}$ & $\begin{array}{l}0.000 \\
1.000\end{array}$ & $\begin{array}{l}0.017 \\
0.983\end{array}$ & $\begin{array}{l}0.029 \\
0.971\end{array}$ & $\begin{array}{l}0.000 \\
1.000\end{array}$ & $\begin{array}{l}0.000 \\
1.000\end{array}$ & $\begin{array}{l}0.000 \\
1.000\end{array}$ & $\begin{array}{l}0.000 \\
1.000\end{array}$ \\
\hline$M n r-a$ & $\begin{array}{l}1 \\
2 \\
3\end{array}$ & $\begin{array}{l}0.034 \\
0.880 \\
0.086\end{array}$ & $\begin{array}{l}0.071 \\
0.893 \\
0.036\end{array}$ & $\begin{array}{l}0.059 \\
0.823 \\
0.118\end{array}$ & $\begin{array}{l}0.250 \\
0.750 \\
0.000\end{array}$ & $\begin{array}{l}0.200 \\
0.775 \\
0.025\end{array}$ & $\begin{array}{l}0.077 \\
0.923 \\
0.000\end{array}$ & $\begin{array}{l}0.098 \\
0.902 \\
0.000\end{array}$ \\
\hline$P g m-a$ & $\begin{array}{l}1 \\
2\end{array}$ & $\begin{array}{l}0.190 \\
0.810\end{array}$ & $\begin{array}{l}0.018 \\
0.982\end{array}$ & $\begin{array}{l}0.235 \\
0.765\end{array}$ & $\begin{array}{l}0.278 \\
0.722\end{array}$ & $\begin{array}{l}0.175 \\
0.825\end{array}$ & $\begin{array}{l}0.000 \\
1.000\end{array}$ & $\begin{array}{l}0.008 \\
0.992\end{array}$ \\
\hline $6 P g d-a$ & $\begin{array}{l}1 \\
2\end{array}$ & $\begin{array}{l}0.017 \\
0.983\end{array}$ & $\begin{array}{l}0.000 \\
1.000\end{array}$ & $\begin{array}{l}0.000 \\
1.000\end{array}$ & $\begin{array}{l}0.000 \\
1.000\end{array}$ & $\begin{array}{l}0.000 \\
1.000\end{array}$ & $\begin{array}{l}0.000 \\
1.000\end{array}$ & $\begin{array}{l}0.000 \\
1.000\end{array}$ \\
\hline $6 P g d-b$ & $\begin{array}{l}1 \\
2\end{array}$ & $\begin{array}{l}0.914 \\
0.086\end{array}$ & $\begin{array}{l}0.638 \\
0.362\end{array}$ & $\begin{array}{l}0.824 \\
0.176\end{array}$ & $\begin{array}{l}0.772 \\
0.278\end{array}$ & $\begin{array}{l}0.700 \\
0.300\end{array}$ & $\begin{array}{l}0.728 \\
0.272\end{array}$ & $\begin{array}{l}0.690 \\
0.310\end{array}$ \\
\hline$P g i-a$ & $\begin{array}{l}1 \\
2\end{array}$ & $\begin{array}{l}0.017 \\
0.983\end{array}$ & $\begin{array}{l}0.000 \\
1.000\end{array}$ & $\begin{array}{l}0.000 \\
1.000\end{array}$ & $\begin{array}{l}0.000 \\
1.000\end{array}$ & $\begin{array}{l}0.000 \\
1.000\end{array}$ & $\begin{array}{l}0.000 \\
1.000\end{array}$ & $\begin{array}{l}0.000 \\
1.000\end{array}$ \\
\hline$P g i-b$ & $\begin{array}{l}1 \\
2 \\
3\end{array}$ & $\begin{array}{l}0.276 \\
0.724 \\
0.000\end{array}$ & $\begin{array}{l}0.304 \\
0.696 \\
0.000\end{array}$ & $\begin{array}{l}0.412 \\
0.588 \\
0.000\end{array}$ & $\begin{array}{l}0.361 \\
0.639 \\
0.000\end{array}$ & $\begin{array}{l}0.200 \\
0.800 \\
0.000\end{array}$ & $\begin{array}{l}0.402 \\
0.598 \\
0.000\end{array}$ & $\begin{array}{l}0.350 \\
0.462 \\
0.188\end{array}$ \\
\hline$S k d h-a$ & $\begin{array}{l}1 \\
2\end{array}$ & $\begin{array}{l}0.724 \\
0.276\end{array}$ & $\begin{array}{l}0.804 \\
0.196\end{array}$ & $\begin{array}{l}0.912 \\
0.088\end{array}$ & $\begin{array}{l}0.842 \\
0.158\end{array}$ & $\begin{array}{l}0.725 \\
0.275\end{array}$ & $\begin{array}{l}0.933 \\
0.067\end{array}$ & $\begin{array}{l}0.876 \\
0.124\end{array}$ \\
\hline
\end{tabular}

$A c o$ : aconitate hydratase; G6pd: glucose 6-phosphate dehydrogenase;

Got: glutamate oxaloacetate transaminase; Idh: isocitrate dehydrogenase; Lap:

leucine aminopeptidase; $M d h$ : malate dehydrogenase; $M n r$ : menadione reductase;

Pgm: phosphoglucomutase; 6Pgd: 6-phosphogluconate dehydrogenase; Pgi:

phosphoglucose isomerase; $S k d h$ : shikimate dehydrogenase.

1:La Spina (I); 2: Pollino (I); 3: Pollino A (I); 4: Pollino B (I); 5: Pollino C (I); 6:

Olimpo (GR); 7: Pindo (GR). 


\section{Allozyme analysis}

For the five Italian populations with seedlots from separate trees, the genotypes of individuals were inferred by examining six endosperms for each tree. Endosperms (140-150) were examined for the two Greek populations for which bulk provenance collections of seeds were available. Thirteen enzyme systems, encoded by 23 gene loci, were analysed by means of starch gel electrophoresis. Details of electrophoretic procedures and the inheritance and linkage relationships of allozyme variants studied are given in Morgante et al. $(1991,1993)$.

Allozyme frequencies, mean number of alleles per locus $(N)$, mean percentage of polymorphic loci $\left(P_{5 \%}\right)$, mean effective number of alleles per locus $\left(n_{\mathrm{e}}\right)$ and

Table 2 Genetic variability measures in Italian and Greek populations of Pinus leucodermis

\begin{tabular}{lccccc}
\hline Population & $\begin{array}{c}\text { Sample } \\
\text { size }\end{array}$ & $N$ & $P_{5 \%}$ & $n_{\mathrm{e}}$ & $H_{\mathrm{e}}$ \\
\hline (1) La Spina (I) & 29 & 1.7 & 47.8 & 1.141 & 0.124 \\
(2) Pollino (I) & 29 & 1.6 & 39.1 & 1.135 & 0.119 \\
(3) Pollino A(I) & 17 & 1.6 & 34.8 & 1.130 & 0.115 \\
(4) Pollino B(I) & 19 & 1.6 & 52.2 & 1.187 & 0.158 \\
(5) Pollino C (I) & 20 & 1.5 & 39.1 & 1.145 & 0.127 \\
(6) Olimpo(GR) & $\dagger$ & 1.3 & 34.8 & 1.122 & 0.109 \\
(7) Pindo (GR) & $\dagger$ & 1.4 & 30.4 & 1.124 & 0.110 \\
\hline
\end{tabular}

$\dagger$ Pooled seed samples.

$N$ : mean no. of alleles per locus.

$P_{5 \%}$ : percentage of polymorphic loci ( $5 \%$ criterion).

$n_{\mathrm{e}}$ : effective no. of alleles per locus (Crow \& Kimura, 1970).

$H_{\mathrm{e}}$ : mean expected heterozygosity. mean expected heterozygosity $\left(H_{\mathrm{e}}\right)$ were calculated. The amount of genetic differentiation between populations at the gene pool level was estimated by calculating $G_{\text {st }}$ (Nei, 1975). Genetic relationships between populations were examined by computing standard genetic distances (Nei, 1972) and using these values in a UPGMA cluster analysis.

\section{Chloroplast DNA analysis}

DNA was extracted from about 80 germinated embryos from each of the seven populations following a modification of the CTAB method (Bousquet et al., 1989; Doyle \& Doyle, 1990).

DNA amplification was performed in a Perkin Elmer 9600 thermal cycler. The typical volume of the reaction mixture was $50 \mu \mathrm{L}$ containing 50 ng DNA, 20 $\mathrm{mm}$ Tris- $\mathrm{HCl}, 100 \mathrm{~mm} \mathrm{KCl}, 0.02$ per cent gelatine, 3 $\mathrm{mm} \mathrm{MgCl}, 0.2 \mathrm{~mm}$ of each nucleotide, $0.2 \mu \mathrm{M}$ of each primer and 1 unit Taq polymerase (commercial preparation). We used two pairs of 20 -mer primers for the PCR placed in very conserved regions flanking more variable regions (purchased from Operon Technologies). The amplified regions are expected to be the intergenic spacers between the $\operatorname{trn} T$ and $\operatorname{trn} L$ genes and between the trnL and $\operatorname{trnF}$ genes of the chloroplast genome (Taberlet et al., 1991). DNA amplification was conducted according to the following programme: (i) a $5 \mathrm{~min}, 95^{\circ} \mathrm{C}$ step for DNA denaturation (hot start), (ii) a $80^{\circ} \mathrm{C}$ step for enzyme addition and (iii) 40 cycles of $1 \mathrm{~min}$ at $94^{\circ} \mathrm{C}, 1 \mathrm{~min}$ at $54^{\circ} \mathrm{C}$ and 2 $\min$ at $72^{\circ} \mathrm{C}$. The last cycle was followed by $8 \mathrm{~min}$ at $72^{\circ} \mathrm{C}$. Amplification products were visualized in a 1.5 per cent agarose gel. Both amplification products were cut with 11 restriction endonucleases (Table 3), all with four base recognition sites.

Table 3 Restriction endonucleases used in Pinus leucodermis and number of restriction sites found

\begin{tabular}{|c|c|c|c|}
\hline \multirow[b]{2}{*}{ Endonuclease } & \multirow[b]{2}{*}{ Recognition sequence } & \multicolumn{2}{|c|}{ No. of restriction sites } \\
\hline & & Fragment A & Fragment B \\
\hline Alu I & ${ }^{5} \mathrm{AG} / \mathrm{CT}^{3 \prime}$ & 1 & 2 \\
\hline CfoI & ${ }^{5 \prime} \mathrm{GCG} / \mathrm{C}^{3 \prime}$ & 1 & 0 \\
\hline$D d e I$ & ${ }^{5} \mathrm{C} / \mathrm{TNAG}^{3 \prime}$ & 0 & 1 \\
\hline HaeIII & ${ }^{5 \prime} \mathrm{GG} / \mathrm{CC}^{3 \prime}$ & 0 & 0 \\
\hline HinfI & ${ }^{5 \prime} \mathrm{G} / \mathrm{ANTC}^{3 \prime}$ & 3 & 2 \\
\hline HpaII & ${ }^{5} \mathrm{C} / \mathrm{CGG}^{3 \prime}$ & 0 & 1 \\
\hline MseI & ${ }^{5 \prime} \mathrm{T} / \mathrm{TAA}^{3 \prime}$ & 0 & 2 \\
\hline$N c i \mathrm{I}$ & ${ }^{5 \prime} \mathrm{CC} /(\mathrm{CG}) \mathrm{GG}^{3 \prime}$ & 1 & 1 \\
\hline RsaI & ${ }^{5 \prime} \mathrm{GT} / \mathrm{AC}^{3 \prime}$ & 0 & 1 \\
\hline Sau 3a & ${ }^{5 \prime} / \mathrm{GATC}^{3 \prime}$ & 0 & 2 \\
\hline TaqI & ${ }^{5 \prime} \mathrm{T} / \mathrm{CGA}^{3 \prime}$ & 3 & 3 \\
\hline
\end{tabular}


To assess the reliability of this PCR/RFLP method for phylogenetic analysis in the genus Pinus, DNA was also extracted and examined from other Pinus species: $P$. brutia, $P$. halepensis, $P$. nigra and $P$. pinaster. We chose these Pinus species because they all belong to the same subgenus, section and subsection as $P$. leucodermis (Little \& Critchfield, 1969). Moreover, P. brutia and $P$. halepensis belong to the same complex and are considered to be very closely related, with $P$. brutia formerly treated as a variety of $P$. halepensis. The comparative analysis of $P$. brutia and $P$. halepensis in particular should act as an appropriate test of the reliability of the chosen PCR/RFLP method for separating very closely related pine species. DNA samples from these species were amplified with primers flanking the region between the $\operatorname{trn} L$ and $\operatorname{trn} F$ genes, then digested with restriction endonucleases.

As a control, DNA was also extracted and amplified from endosperm tissue, which is of maternal origin. In most conifers, chloroplasts are inherited paternally and amplication of cpDNA is therefore not expected to occur from endosperm tissue. Digestion products were visualized in 3 per cent agarose gel after ethidium bromide staining.

\section{Results}

\section{Allozyme analysis}

Sixteen of the 23 isozyme loci investigated were polymorphic in at least one population (Table 1). The seven monomorphic loci were Gdh-a (glutamate dehydrogenase), Idh- $a, M d h-a, M d h-c, M n r-b, N d h-a$ (NADH dehydrogenase) and $S k d-b$. Greek populations were characterized by the absence of rare alleles that were present in Italian populations. Also, Greek populations were often fixed for a particular allele at a locus while Italian populations were polymorphic for two or more alleles. At the Lap-b locus the frequency of the $b 1$ allele was much lower in Greek populations, particularly the Olimpo population. Furthermore, allele $b 3$ at the Pgi- $b$ locus was scored only in the Pindo population while at locus G6pd-a the most frequent allele in the Pindo population was $a 1$ instead of $a 2$.

A summary of measures of genetic variability in populations is given in Table 2. In general, it is evident that the level of genetic variability is lower in the Greek populations than in the Italian populations.

The mean level of genetic differentiation between populations over all loci estimated using $G_{\text {st }}$ (Table 4) was 0.054 , thus indicating that less than 5.5 per cent of the total genetic diversity is explained by differences between populations. Some loci, e.g. Lap-b, G6pd-a and Got- $a$, contributed particularly more than others to the observed levels of differentiation among populations (16, 11 and 11 per cent, respectively).

Genetic distance values (Table 5) were in general low, again indicating a low degree of genetic divergence

Table 4 Genetic diversity analyses for Pinus leucodermis

\begin{tabular}{lcccc}
\hline Locus & $H_{\mathrm{t}}$ & $H_{\mathrm{s}}$ & $D_{\mathrm{st}}$ & $G_{\mathrm{st}}$ \\
\hline Aco- $a$ & 0.179 & 0.171 & 0.009 & 0.050 \\
G6pd- $a$ & 0.475 & 0.422 & 0.053 & 0.112 \\
Got $-a$ & 0.134 & 0.119 & 0.015 & 0.113 \\
Got $-b$ & 0.035 & 0.034 & 0.001 & 0.019 \\
Got $-c$ & 0.077 & 0.073 & 0.003 & 0.043 \\
Idh- $b$ & 0.038 & 0.037 & 0.001 & 0.029 \\
Lap- $a$ & 0.097 & 0.094 & 0.003 & 0.026 \\
Lap- $b$ & 0.371 & 0.313 & 0.058 & 0.157 \\
Mdh- $b$ & 0.013 & 0.013 & 0.001 & 0.018 \\
Mnr- $a$ & 0.264 & 0.253 & 0.011 & 0.043 \\
Pgm- $a$ & 0.225 & 0.201 & 0.024 & 0.105 \\
6Pgd- $a$ & 0.005 & 0.005 & 0.000 & 0.015 \\
6Pgd- $b$ & 0.380 & 0.365 & 0.015 & 0.039 \\
Pgi- $a$ & 0.005 & 0.005 & 0.000 & 0.015 \\
Pgi- $b$ & 0.476 & 0.457 & 0.019 & 0.041 \\
Skdh- $a$ & 0.281 & 0.269 & 0.012 & 0.043 \\
Mean & 0.191 & 0.177 & 0.014 & 0.054 \\
\hline
\end{tabular}

$H_{\mathrm{t}}$ : total gene diversity; $H_{\mathrm{s}}$ : gene diversity within populations; $D_{\mathrm{st}}$ : gene diversity among populations; $G_{\mathrm{st}}$ : relative degree of genetic differentiation.

See Nei $(1973,1975)$.

Table 5 Genetic distances between populations of Pinus leucodermis calculated following Nei (1972)

\begin{tabular}{lccccccc}
\hline Population & 1 & 2 & 3 & 4 & 5 & 6 & 7 \\
\hline (1) La Spina (I) & $* * * *$ & & & & & & \\
(2) Pollino (I) & 0.010 & $* * * *$ & & & & & \\
(3) Pollino A (I) & 0.005 & 0.009 & $* * * *$ & & & & \\
(4) Pollino B (I) & 0.008 & 0.010 & 0.006 & $* * * *$ & & & \\
(5) Pollino C(I) & 0.006 & 0.009 & 0.007 & 0.005 & $* * * *$ & & \\
(6) Olimpo (GR) & 0.018 & 0.013 & 0.017 & 0.020 & 0.018 & $* * * *$ & \\
(7) Pindo (GR) & 0.025 & 0.011 & 0.020 & 0.018 & 0.023 & 0.007 & $* * * *$ \\
\hline
\end{tabular}


among populations. The largest genetic distances were found between the Italian and Greek populations; the average distance between the two groups was 0.016 , i.e. about three to four times that within groups $(0.004$ and 0.005 , respectively). The UPGMA dendrogram based on the Nei's genetic distances exhibited two major sub-branches, one containing the Italian populations, the other the Greek ones (Fig. 1). Therefore, the dendrogram shows a clear geographical pattern of genetic variation between these two groups of populations.

\section{Chloroplast DNA analysis}

Two cpDNA fragments were amplified representing two intergenic spacers between the $\operatorname{trn} T$ and $\operatorname{trnL}$ genes (fragment A) and the $\operatorname{trnL}$ and $\operatorname{trnF}$ genes

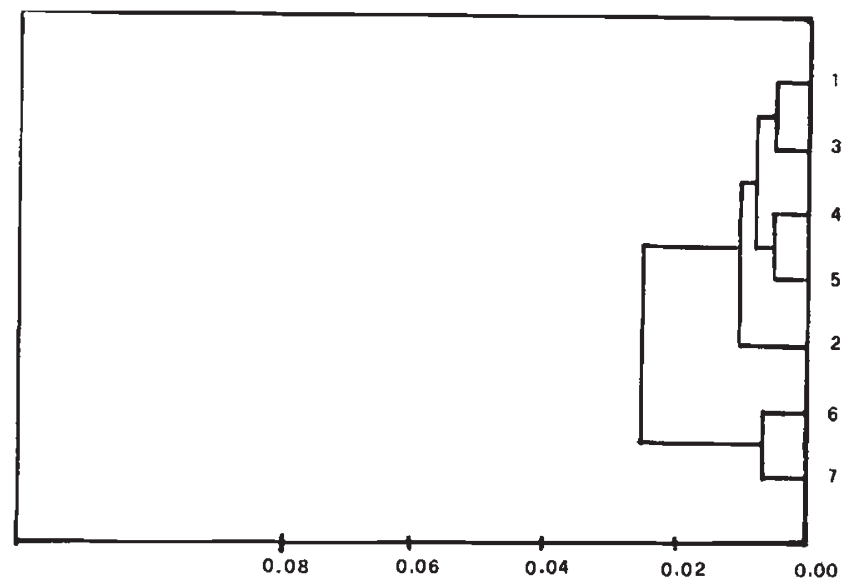

Fig. 1 UPGMA dendrograms based on Nei's genetic distances. Population numbers refer to Tables 1 and 2 . (fragment B). No differences in the sizes of the two amplified products were found among the populations with agarose gel electrophoresis. The estimated fragment sizes were 520 and $500 \mathrm{bp}$, respectively. These fragments have been amplified in other conifer species e.g. Pinus nigra (Taberlet et al., 1991), Picea jezoensis, $P$. koraiensis and P. pungens (G. Boscherini \& G. G. Vendramin, unpublished data) and estimated to vary between 480 and $600 \mathrm{bp}$ in length.

No differences in size were found between the amplification products of $P$. brutia, $P$. halepensis, $P$. leucodermis and $P$. pinaster $(500 \mathrm{bp})$, while the amplification product of $P$. nigra was smaller $(480 \mathrm{bp})$.

Only five out of the 11 restriction enzymes used succeeded in digesting fragment $A$, yielding nine restriction sites (Table 3 ). Fragment $\mathrm{B}$ was digested by nine of the 11 enzymes used, corresponding to 15 sites. No differences at the 24 restriction sites were found among the studied populations. Thus the six populations classified as $P$. leucodermis (Pollino, Pollino A, B, $\mathrm{C}$, La Spina, Olimpo) and the one of uncertain classification (Pindo) yielded identical restriction fragment length profiles over all individuals studied (Fig. 2).

Digestion of fragment B with $M s e I$ and TaqI showed different restriction patterns among $P$. brutia, $P$. halepensis, $P$. leucodermis, $P$. nigra and $P$. pinaster (Fig. 3).

DNA purified from endosperm tissue failed to amplify with the above-mentioned four cp-primers.

\section{Discussion}

Differences between Greek and Italian populations of Pinus leucodermis were evident from the allozyme

FRAGMENT A

FRAGMENT B

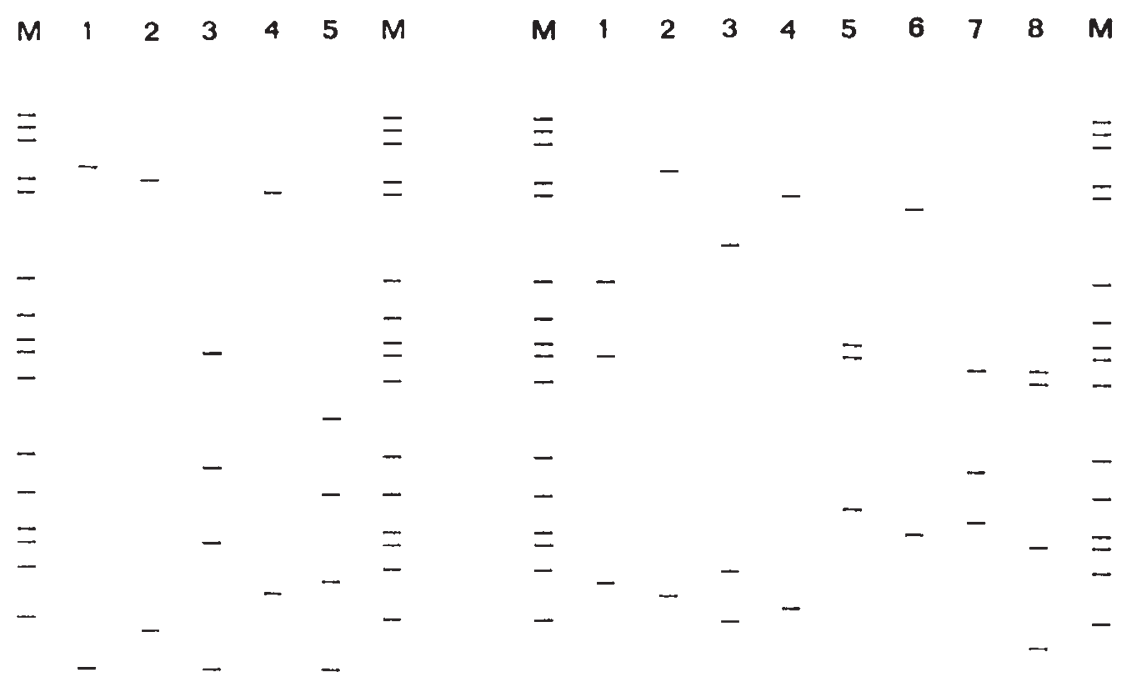

Fig. 2 Restriction patterns of fragments $\mathrm{A}$ and $\mathrm{B}$ obtained using different restriction enzymes (fragment $\mathrm{A}: 1$ : AluI; 2: CfoI; 3: HinfI; 4: NciI; 5: TaqI; fragment B: 1: AluI; 2: DdeI; 3: HinfI; 4: HpaII and NciI; 5: MseI; 6: RsaI; 7: Sau 3a; 8: TaqI); M: pBR322-HaeIII digest molecular weight marker (Boehringer). The restriction patterns are identical for all the studied populations of $P$. leucodermis. 


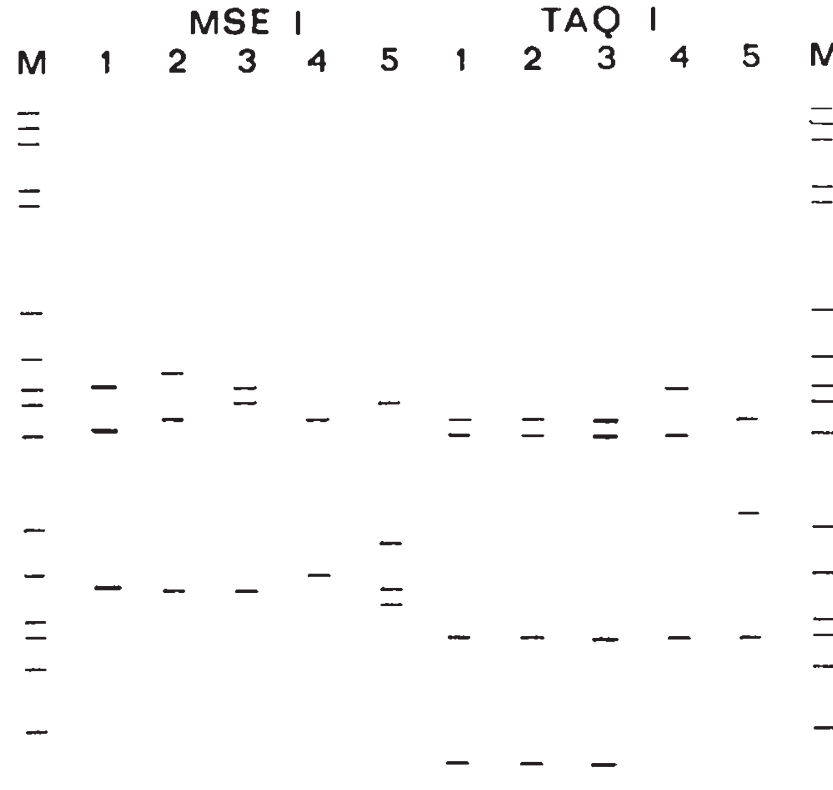

Fig. 3 Restriction patterns of fragment B in 1: Pinus brutia, 2: $P$. halepensis, 3: $P$. leucodermis (Pollino), 4: $P$. nigra, 5: $P$. pinaster using MseI and TaqI. M: pBR322-HaeIII digest molecular weight marker (Boehringer).

analysis. The two Greek populations were characterized by a lower level of genetic variability, mainly because of the absence of rare alleles in these populations. However, differences in the distributions of rare alleles were observed even among the three neighbouring Italian populations (Pollino A, B and C). This distribution could be due to sampling errors caused by small sample size or reflect the ecological characteristics of this species, in particular the low density and the discontinuity of the stands, which could prevent gene flow. Local populations may also have experienced genetic bottlenecks leading to a loss of different alleles. Reduction in population sizes could have occurred in the past, because it has been documented (Avolio, 1984) that the species range was once much larger and has since been dramatically reduced to a few small sites. The Greek populations can be distinguished quite clearly from the Italian ones at the gene pool level, even if the values of the genetic distance between the two groups of populations are too low to suggest that they represent two different species. Shurkhal et al. (1992) found that values of Nei's genetic distance between species belonging to the Pinus and Strobus subgenera (classification of Little \& Critchfield, 1969) ranged between 1.42 and 2.66, with an average value of 2.17 .

Identical amplified cpDNA products and cpDNA restriction patterns were observed among all individuals of $P$. leucodermis examined: these observations assume more relevance given that the regions analysed are noncoding regions which may be expected to display a high level of polymorphism (Palmer et al., 1988; Clegg et al., 1991). The efficiency of this method for the classification of different Pinus species has been demonstrated by the RFLP analysis of fragment B. Using this approach, $P$. brutia, $P$. halepensis, $P$. leucodermis, $P$. nigra and $P$. pinaster were easily distinguished providing clear evidence that closely related species of pine can normally be identified in this way.

On the basis of both allozymes and cpDNA analyses, it can be concluded that all seven studied populations of $P$. leucodermis probably belong to the same biological species, the differences scored at the isozyme level between the two geographical groups being due to their different evolutionary history. Our results are in accordance with those reported by Mirov (1967), who considered $P$. leucodermis and $P$. heldreichii as the same species.

Chloroplast DNA has been found to be paternally inherited in all the conifers that have been examined (Neale et al., 1986, 1989, 1991; Szmidt et al., 1987, 1988; Neale \& Sederoff, 1989; Stine et al., 1989; Wagner et al., 1989, 1992). The lack of amplification using DNA isolated from the seed megagametophyte of $P$. leucodermis would suggest a similar mode of inheritance in this species.

\section{Acknowledgements}

This research was partly supported by the E.C. (BIOTECH project-B102 CT93 0373).

\section{References}

Avolio, S. 1984. Il pino loricato (Pinus leucodermis Ant.). Ann. Ist. Sper. Selv., XVII, 79-153.

BousQuet, J., CHELIAK, v. M. AND LALONDE, M. 1989. Genetic differentiation among 22 mature populations of green alder (Alnus crispa) in central Quebec. Can. J. For. Res., 17, 219-227.

CLEGG, M. T., LEARN, G. H. AND GOLENBERG, E. M. 1991. Molecular evolution of chloroplast DNA. In: Selander, R. K., Clark, A. G. and Whittman, T. S. (eds) Evolution at the Molecular Level, pp. 135-149. Sinauer Associates, Sunderland, MA. CROW, J. F. AND KIMURA, M. 1970. An Introduction to Population Genetics Theory. Harper and Row, New York.

DOYLE, J. J. AND DOYLE, J. L. 1990. Isolation of plant DNA from fresh tissue. Focus, 12, 13-15.

LISTON, A. 1992. Variation in the chloroplast genes rpo C1 and rpo $\mathrm{C} 2$ of the genus Astragalus (Fabaceae): evidence from restriction site mapping of a PCR-amplified fragment. Am. J. Bot., 79, 953-961.

LITTLE, E. L. AND CRITCHFIELD, W. B. 1969. Subdivisions of the genus Pinus (pines). U. S. Dep. Agric. Misc. Publ. No. 1144. 
MIRov, N. T. 1967. The genus Pinus. Ronald Press Company, New York.

MORGANTE, M., VENDRAMIN, G. G. AND GIANNINI, R. 1993. Inheritance and linkage relationships of isozyme variants of Pinus leucodermis Ant. Silvae Genetica, 42, 231-236.

MORGANTE, M., VENDRAMIN, G. G. AND OLIVIERI, A. M. 1991. Mating system analysis in Pinus leucodermis Ant: detection of self-fertilization in natural populations. Heredity, 67, 197-203.

NEALE, D. B., MARSHALL, K. A. AND HARRY, D. E. 1991. Inheritance of chloroplast and mitochondrial DNA in incense cedar (Calocedrus decurrens). Can. J. For. Res., 21, 217-220.

NEALE, D. B., MARSHALL, K. A. AND SEDEROFF, R. R. 1989. Chloroplast and mitochondrial DNA are paternity inherited in Sequoia sempervirens D. Don Endl. Proc. Natl. Acad. Sci. U.S.A., 86, 9347-9349.

NEALE, D. B. AND SEDEROFF, R. R. 1989. Paternal inheritance of chloroplast DNA and maternal inheritance of mitochondrial DNA in loblolly pine. Theor. Appl. Genet., 77, 212-216.

NEALE, D. B., WHEELER, N. C. AND ALlaRD, R. w. 1986. Paternal inheritance of chloroplast DNA in Douglas fir. Can. J. For. Res., 16,1152-1154.

NEI, M. 1972. Genetic distance between populations. Am. Nat., 106, 282-292.

NEI, M. 1973. Analysis of gene diversity in subdivided populations. Proc. Natl. Acad. Sci. U.S.A., 70, 3321-3323.

NEI, M. 1975. Molecular Population Genetics and Evolution. North Holland Publishing, Amsterdam, Oxford.

PALMER, J. D., JANSEN, R. K., MICHAELS, H. J., CHASE, M. W. AND MANHART, J. R. 1988. Chloroplast DNA variation and plant phylogeny. Ann. Mo. Bot. Gard., 75, 1180-1206.

RIESEBERG, L. H., HANSON, M, AND PHILBRICK, C. T. 1992. Androdioecy is derived from dioecy in Datiscaceae: evidence from restriction site mapping of PCR-amplified chloroplast DNA fragments. Syst. Bot., 2, 324-336.
SHURKhal, A., PODOGAS, A. AND ZHIVOTOVSKY, L. 1992. Allozyme differentiation in the genus Pinus. Silvae Genetice., 41, 105-109.

SIGURGEIRSSON, A. AND SZMIDT, A. E. 1988. Chloroplast DNA variations among North American Picea species and its phylogenetic implications. In: J. E. Hallgren (ed.) Molecular Genetics of Forest Trees. Proceedings of the Frans Kempe Symposium, Swedish University of Agricultural Sciences, Umea, Sweden.

STINE, M., SEARS, B. B. AND KEATHLEY, D. E. 1989. Inheritance of plastids in interspecific hybrids of blue spruce and white spruce. Theor. Appl. Genet., 76, 841-845.

SZMidT, A. E., ALDEN, T. AND HALlgREN, J. E. 1987. Paternal inheritance of chloroplast DNA in Larix. Plant. Mol. Biol., 9, 59-64.

SZMIDT, A. E., EL-KASSABY, Y. A., SIGURGEIRSSON, A., ALDEN, T., LINDGREN, D. AND HALLGREN, J. E. 1988. Classifying seedlots of Picea sitchensis and P. glauca in zones of introgression using restriction analysis of chloroplast DNA. Theor. Appl. Genet., 76, 841-845.

TABERLET, P., GIELLY, L., PAUTOU, G. AND BOUVET, J. 1991. Universal primers for amplification of three non-coding regions of chloroplast DNA. Plant Mol. Biol., 17, 1105-1109.

WAGNER, D. B., GOVINDARAJU, D. R., YEATMAN, C. W. AND PITEL, J. A. 1989. Paternal chloroplast DNA inheritance in a diallel cross of jack pine (Pinus banksiana Lamb). J. Hered., 80, 483-485.

WAGNER, D. B., NANCE, W. L., NELSON, C. D., LI, T., PATEL, R. N. AND GovindaraJU, D. R. 1992. Taxonomic patterns and inheritance of chloroplast DNA variation in a survey of Pinus echinata, Pinus elliottii, Pinus palustris and Pinus taeda. Can. J. Forest. Res., 22, 683-689.

WANG, X. R. AND SZMIDT, A. E. 1990. Evolutionary analysis of Pinus densata (Master) a putative Tertiary hybrid. II. A study using species-specific chloroplast DNA markers. Theor. Appl. Genet., 80, 641-647. 